\title{
Selected aspects of strategic management in the service sector
}

\author{
Jan Dvorský \\ Tomas Bata University in Zlín, Zlín, Czech Republic \\ Zora Petráková \\ Slovak University of Technology, Bratislava, Slovak Republic \\ Khurram Ajaz Khan \\ Tomas Bata University in Zlín, Zlín, Czech Republic \\ Ivo Formánek \\ University of Entrepreneurship and Law, Prague, Czech Republic \\ Zdeněk Mikoláš \\ University of Entrepreneurship and Law, Prague, Czech Republic
}

Received: 21 April 2020. Revision received: 10 May 2020. Accepted: 15 May 2020.

\begin{abstract}
The focus of the present paper is to identify and defines the important factors of strategic management in SMEs with a specific focus on the service sector and to compare its current situation in the Czech Republic and Slovak republic firms. To shape the study, survey-based research planned and conducted in the Czech Republic and Slovak republic over SMEs in the service sector. The data were collected from the owners or top-level managers, the total sample used in the study was 822,454 respondents from the Czech firms and 368 firms from the Slovak republic. The study employs basic statistics tools, percentages and mean values, used Z-score to compare the respondents in the Czech Republic and Slovak republic. The major findings of the study reveal that majority of the firms in both the countries use strategic management as an integral part of corporate governance and believe that strategic management usage improves the competitiveness of the firms and its stability in domestic and foreign markets. Another interesting finding reveals that the business sector is not a statistically significant factor in evaluating the sources of strategic risk, found from the firms of both countries. The paper adds to the existing literature of SMEs, investigated the use of strategic management tools for their sustainability and competitiveness. As the key aspects of strategic management are much used in large size organization but less explored in the smaller segment. The outcome of the study can help to understand the SMEs' attitude towards strategic management usage. It is very useful for long term survival, stability, and expansion, as both countries' economy is heavily depending on the SMEs.
\end{abstract}

Key Words: small and medium enterprises, service sector, strategy, strategic management, Czech Republic, Slovak Republic.

JEL Classification: L26.

Reference: Dvorský, J., Petráková, Z., Ajaz Khan, K., Formánek, I., \& Mikoláš, Z. (2020). Selected aspects of strategic management in the service sector. Journal of Tourism and Services, 20(11), 109-123. doi: 10.29036/jots.v11i20.146.

\section{Introduction}

SMEs in Europe are the main employment creator (Nosková \& Peráček, 2019), hold a big share in the country's total innovation, are also a major source of export and tax generator for the states (Williams et al., 2019; Cepel et al., 2018; Kalchenko et al., 2018; Hudakova et al., 2018). Knowing its importance, nations constantly support and take efforts to establish congenial policies towards their 


\section{JOURNAL OF TOURISM AND SERVICES}

Issue 20, volume 11, ISSN 1804-5650 (Online)

www.jots.cz

sustainability and economic growth (Kisel'áková et al., 2019). But the question is, one-sided support, is it enough for the SMEs sustainability, what SMEs have to do, out of their abilities to survive and grow, is state support is enough for the growth and development, what they need to do, not only to survive but to achieve its long-term goals, competitiveness, and long-term strategic advantage to sustain in the dynamic market. A lot depends on the SMEs' approach, how each SMEs manage their business operation, achieve their set goals, and sustain in the competition. SMEs in the whole of Europe have routine challenges such as to comply with rules and regulations, information accessibility, market, and financing decisions (European Commission, 2020). On one hand, previous studies show that strategic management implementation in the organizations is very fruitful and useful in the organization in several ways such as it gives a direction to the organization in the form of mission and vision statements, long term goals setting, enable firms to create plans and policies for the smooth business operations. But the point of concern is, various studies also indicate that a limited number of SMEs are only adopting strategic intent such as vision and mission, unlike big size corporates, and very few uses business plans in their operations. It is also questionable whether these practices in SMEs can influence business performance and success (Frantz et al., 2017). On the other hand, many SMEs are facing challenges whether they will survive in the competitive market or not and they are constantly exploring the way out, in this regards, the emerging question is, whether strategic management usage and implementation in SMEs can be useful as an instrument to increase competitive advantage and firms' competitiveness for the longer sustainability (Švárová \& Vrchota, 2013; Lewandowska \& Stopa, 2018; 2019).

Strategic management is concerned with the long-term success of the firms and is a vehicle through which managers can design for the future (Stonehouse \& Pemberton, 2002; SzczepańskaWoszczyna, 2018). Strategic management consists of strategy formulation, strategy implementation, and strategy evaluation to achieve the long-term set objectives of the business, and the people who frame and implement strategic management can be the owners, managers, or entrepreneurs. These people should have the right knowledge and competencies to overcome sustainable development challenges (Fonseca et al., 2018). Therefore, a lot depends on the attitude of those key people how they adopted, perceived, plan, and implement. Studies claim that strategic management depends on the business owners, managers, and leaders who think, analyze, and implement long-term goals, give direction, and frame welldefined plans to counter major challenges and issues concerning the organization's development and growth (Frantz et al., 2017). In the current scenario, strategic management is an integral part of every type and size of the business, whether large, medium or small, plays an imperative role in the success of any business operation. The strategic managers are responsible for identifying the strategies, and in SMEs, owners can be the strategic managers, unlike large corporations. So, the key person responsible for the strategic management process might be the owner of the SMEs (Fuertes et al., 2020). Strategic management is about the manager's capability to supervise, control, interpret, and manage the dynamic external and internal environment (Barbosa et al., 2020). Hence, it depends on how the owners/managers implement strategic management and depend on the managers' perception, approach, and understanding as different managers may have a different approach towards it (Felício, 2013; Ungerman et al., 2018; Kot et al., 2019).

The current study will investigate the selected aspects of strategic management such as competitiveness, strategic risk management, strategic management relationship with corporate governance, etc. in SMEs belongs to the service sector. The study compares the SMEs in the service sector in the Czech Republic and Slovakia as they share a common business history and other similarities in business set-ups. The article aims are to define important factors of strategic management in the service sector and compare the situation in the Czech Republic and the Slovak Republic. Also, identify the statistical differences about important factors between the service firms in the Czech Republic and Slovakia. The outcome of the study can help identify the importance of strategic management, its key aspects, and how managers/owners perceived its relevance and implement in their business operations in the service sector specifically in the SME segment. The results of the study will be helpful for the emerging SMEs in the service sector, to understand the critical success factor of strategic management 


\section{JOURNAL OF TOURISM AND SERVICES}

Issue 20, volume 11, ISSN 1804-5650 (Online)

www.jots.cz

implementation and can use it for their competitive growth and sustainability in the dynamic business environment within their economies. A study found that big size firms use more long-term plans and other tools of strategic management but SMEs stress more in short term (Stonehouse \& Pemberton, 2002). This is another motivation to conduct the study specifically on SMEs of Czech and Slovak republic.

The paper is designed in four broad sections in the following sequence. The first section consists of a theoretical background. The second section will explain the aim, data collection and methods applied. The third section is about data analysis, results, and hypothesis testing. The final stage includes discussion and conclusion inclusive of limitations and future research scope.

\section{Literature review}

The current literature review explores how the key aspects of strategic management are important for SMEs' competitiveness (Ivanova et al., 2019). and sustainability (Kot, 2018), especially those who belong to the service sector. The literature review is divided into two sections. The first section identifies and evaluates the key factors of the strategic management that are believed to have an impact on the firm's performance in the service sector. The second part will establish the relationship between the factors of strategic management and firms' sustainability.

Proper and organized use of strategic management can help the business to achieve better outcomes and competitiveness than just using informal ways of business management (Carreras et al., 2018; Cešnovar, 2006). Looking it through the corporate governance direction, which includes contents such as ethics codes and corporate responsibilities, which now have an integral part somehow in companies' vision and mission statements (Androniceanu, 2019; Korzh et al., 2017). The creation of new talent pools through coopetitive cooperations by making use of a simplified version of the overarching and dynamic multilevel model of coopetition is a very important aspect for a better company's outcome (Foerster-Pastor et al., 2019). It was also found successful firms who implement corporate governance items, even partially and indirectly in strategic management they achieve financial steadiness and sustainability (Saltaji, 2013). Therefore, the present study undertakes this phenomenon that the strategic management in a company can be an integral part of corporate governance as it shows its relevance to modern business management. Another aspect of the present study is the service sector as a services sector is the major contributor to economic growth and generation of employment in the European Union, constitute almost two-thirds of both European union employment and value addition (European Commission, 2016). Whether it's a developed or developing nation, the future economic growth will be driven by their competitiveness, in services rather than in manufacturing, this reflects the importance of expanding service sectors (Wirtz et al., 2015; Androniceanu \& Tvaronavičienė, 2019). Modern business concept claims no business can be separate from some kind of services, even a pure manufacturing firm has to offers services to customers and users, therefore more or less service sector importance is related with the firm success, and all kind of firms needs to be equipped with strategic intent for the firm's successful operations, and the same is the target segment for the present study. It is always imperative to all the organizations to analyze its environment to identify the threats and opportunities and to frame the optimal and most appropriate strategies to achieve its long-term objectives and this process is not only important for manufacturing firms but also in the service sector (Volkova, 2015). Project management practice is an important tool in increasing higher business performance, particularly in social enterprises (Kubíčková and Hodžić, 2019).

Corporate governance includes law, rules and regulations, efficient and fair usage and allocation of resources, and its preservation to prolong its availability and economic benefits to all the stakeholders in the society (Saltaji, 2013). Corporate governance is about assurance and compliance, it is about rules, processes, and procedure used to direct and manage business operations and the key people who manage these responsibilities are the part of the board of director or management (Arunruangsirilert \& 


\section{JOURNAL OF TOURISM AND SERVICES}

Issue 20, volume 11, ISSN 1804-5650 (Online)

www.jots.cz

Chonglerttham, 2017; Honggowati et al., 2017). On the other hand, strategic management is about external and internal analysis to understand threats and opportunities in the environment, strategy formulation, implementation through plans and policies, and evaluation and control (Parnell, 2014; Pisar \& Bilkova,2019). Looking into the similarities between strategic management and corporate governance, it lies within the polices, plans, and course of action of the firm. The organizations must share their interest with the community, and society, profits must reflect the outcome of the ethical and right things and actions. Resources must be used in such a way to ensure its preservation and long-term availability. To inculcate the same in their long-term objectives, managers have to think strategically, consider the ethical issues, responsibilities, and conscientiousness managers have to extend their parameters and should not think within the organizational goals only (Barbosa et al., 2020).

Corporate governance provides compliance and assurance to be followed in business, and it is not a tool itself for business success. Issues arise from conflicting and unbalancing between directors or board members to ensure both performance and conformance (Arunruangsirilert \& Chonglerttham, 2017). Corporate governance gives a wide guideline towards fairness and compliance, and mangers can frame their strategic intent within the boundaries of the corporate governance, which shows strategic management ca be implemented with the broad corporate governance guidelines. In the absence of effective corporate governance, managers can think of taking strategic decision that can benefit their own goals rather than the shareholders, it means corporate governance effects strategic management and the inverse relationship was also found that the strategic management also affects the firm's corporate governance (Shen \& Gentry, 2014). It shows how both are related to each other, as corporate governance is more related to fairness, law, and compliance and strategic management is within the firm to achieve its long-term goals, strategic management deemed to be an integral part of corporate governance.

Even a good strategy can fail if the implementation is not appropriate and controlled. Many authors believe that strategy implementation is more critical than strategy formulation (Andrews et al., 2017). Many firms fail as there is no organized plans or model which can guide the implementation of the strategy, how the action plan can be implemented in daily routines and how can the set objectives can be achieved that's a big challenge to many firms (Günther, 2016). Plans, policies, and procedure are framed by the top-level managers, to implement middle-level managers break it into sub-plans and policies, and the functional level employees put it into practice in the everyday job, therefore, ensuring everyday implementation of framed policies and plans to ensure the actions are taken towards the master plan and policies. It is the responsibility of the managers to ensure the implementation of set plans and policies in their day to day operations (Elbanna et al., 2016). Fail to follow plans and frame guidelines in routines actions may lead to failure or underachievement of the framed objectives which in any situation seems to be unfavourable for business growth and development. Therefore, it is majorly depending on the managers and entrepreneurs to ensure the implementation of the set plans, procedures, and regulations in the daily routine of the business operations. Using rational arguments of economic or business type in the attempt to attract investors, increase SME's competitiveness by driving new investments to the firm (Lyulyov et al., 2017; Fernández-Vázquez and Álvarez-Delgado, 2019).

To build long-term competitiveness, strategic management is imperative for the firms and becomes even more vital if a firm is going through the crisis. Managers following strategic management have better preparation to cope up during critical situations, sustain and can look forwards to grab the advance opportunities in the future. Another study found that strategic planning in SMEs influence business competitiveness (Carreras et al., 2018; Buganová \& Hudáková, 2015). Therefore, it makes significant for the firms to follow strategic planning which ultimately enhances firm's competitiveness to sustain in the competition, develop their competitive advantage and convert it into long term strategic advantages to develop their competitive edge over others (Vrchota \& Rehor, 2017). Strategic management gives direction to firms regarding their resources and capabilities, which ultimately helps the firms to develop their competitiveness (Gallardo-Vázquez \& Lizcano-Álvarez, 2020). Having strong competitiveness in the markets gives the ability to firms to expand their geographical expansion, which can bring wide opportunities for the firms and brings stronger stability to firms. Not only to identify the 


\section{JOURNAL OF TOURISM AND SERVICES}

Issue 20, volume 11, ISSN 1804-5650 (Online)

www.jots.cz

opportunities from the environment as early as possible, managers but investigate the threat of any crisis or challenges which can spoil the opportunities and can be a possible threat to the firms' operations (Vrchota \& Rehor, 2017; Mura et al., 2018).

Strategic risks can affect the firm's brand image negatively, can affect the firm's competitiveness, poor technological innovation, regulatory issues, etc. Risk is about uncertainty and it cannot be separate from the operations of the organizations. As declared by Valaskova et al. (2018), the identification of significant factors and determinant of corporate risk may influence the overall prosperity of enterprises. Knowing, how to identify the risks, how to design an action plan to minimize it, how to monitor and control it, can be helpful for the firms to survive and sustainability especially for SMEs (Durica et al., 2019). Why this is more severe and essential in SMEs they are highly exposed to harmful effect because of having very limited resources and supports (Verbano \& Venturini, 2013). Fewer means and limited resources make the challenge for SMEs bigger than large size organization, which itself showcase how important is strategic management implementation for SMEs' survival and growth (Williams et al., 2019). Strategic risk management is a serious concern in firms, evidence reveal the reasons behind the failure of many businesses is poor risk management, due to the failure of evaluating the right amount and type of risks. Its mismanagement can bring dire consequences on business even wrong judgment can lead the bankruptcy of the firms (Drew et al., 2006). The successful operation of the business includes regular monitoring, evaluation, and compliance with the framed strategy to manage the identified risk and avoid the flaw in the business activities. It depends on the managers again how they ensure and manage strategic risk in the business daily operations (Ključnikov et al., 2016; Korzh et al., 2017).

In this context, Belas et al. (2020) showed in result of the research that the importance of business ethics is viewed very highly in both countries, with the structure of the answers of Czech and Slovak entrepreneurs being found to be very similar. Also, the authors found that women have a higher awareness of business ethics than men, as were entrepreneurs and managers with a higher education compared to those who have a secondary education.

Strategic planning tools, environmental scanning, strategic thinking can help to reduce failure chances of SMEs. Poor awareness about key strategic management tools rather than the perception of managers could be a basic reason for the under-utilization of strategic management in SMEs (Stonehouse \& Pemberton, 2002). In short, a lot depends on the SMEs, precisely, it is on the attitude of managers in SMEs, how much importance they give to strategic management usefulness. Its implementations along with corporate governance, using strategic management formally through plans and policies, implement, manage, evaluate and control in routine business operations along with management of strategic risk to safeguard from threat and avail opportunities to acquires long term strategic advantage and competitiveness. Therefore, it is vital to understand the strategic management usage behavior of SMEs, as its keys aspects are undoubtedly useful for the success of the firms across the world.

\section{Aim, methodology, methods and data}

The aim of the article is to define important factors of strategic management in the service sector and compare the situation in the Czech Republic and the Slovak Republic. This topic was a part of an extensive research of the Management, business risks and bankruptcies in the small and medium enterprises segment conducted at Tomas Bata University (and other partners' universities) from 01.09.2019 to 04.03.2020 in Zlin in 2019/2020.

The random selection method based on the mathematical function "Rand between" was used to select SMEs from "CRIBIS" in both countries. Subsequently, SMEs were addressed via an email requesting to fulfil out an online questionnaire. The questionnaire was intended for the owner of the companies or the top managers of these companies (hereinafter referred to as "respondents"). The response rate in the Czech Republic was approx. 5.7\% (the number of addressed entrepreneurs was more 


\section{JOURNAL OF TOURISM AND SERVICES}

Issue 20, volume 11, ISSN 1804-5650 (Online)

www.jots.cz

than 8 000). The number of addressed businesses in the Slovak Republic was more than 10000 . The response rate of completed questionnaires was approx. 3.7\%.

The questionnaire covered (77questions): a) basic characteristics of entrepreneurs and their enterprise- the locality of entrepreneurship (region of residence), the sector of the economy; the size of the enterprise; the type of enterprise; gender; age and the level of education of an entrepreneur; b) enterprise risks assessment - market risk, strategic risk, financial risk, personal risk, legal and operational risk; c) risk management - how do respondents identify and quantify risks in their company; d) the attitudes of respondents of statements of the bankruptcy of small and medium-sized enterprises. The research team used the data from 14 statements $(18.4 \%$ of all $)$ from the online questionnaire for this paper. We have managed to collect the total of $822(100 \%)$ fulfilled questionnaires, 454 of them were from the Czech enterprises (55.2\%) and 368 were from their Slovak enterprises (44.8\%).

The questionnaire was created in two versions according to the nationality of respondent. Slovak version is available at: https://forms.gle/rzX3qYeqrcqRFeAF6 and the Czech version is available at: https://forms.gle/okjZypAru4BpSHFb8.

The respondents could comment on the strategic risk (SR) and their sources (SR1, SR2, SR3, and SR4) by one of the following answers (Likert scale): I strongly agree (Quantitative number-answer A1), I agree (A2), I neither agree nor disagree (A3), I disagree (A4) and I strongly disagree (A5).

The statements of the strategic risk are:

SR1: Strategic management in a company is an integral part of corporate governance.

SR2: Strategic management is implemented in the everyday life of our company and realised through action plans and programs.

SR3: Proper strategic management improves the competitive ability of our company and its stability in domestic and foreign markets.

SR4: Our company regularly monitors, evaluates and manages strategic risks.

The authors formulated the following null statistical hypotheses:

H1: There are statistically significant differences between attitudes of respondents on the selected sources of the strategic risk in the Czech Republic (H1_CR) and in the Slovak Republic (H1_SR).

H2: The business sector is no statistically significant factor of evaluating the sources (SR1, SR2, SR3, and SR4) of strategic risk (H2_SR1, H2_SR2, H2_SR3, and H2_SR4) between respondents of the Czech enterprises.

H3: The business sector is no statistically significant factor of evaluating the sources (SR1, SR2, SR3 and SR4) of strategic risk (H3_SR1, H3_SR2, H3_SR3 and H3_SR4) between respondents of the Slovak enterprises.

H4: The business sector is no statistically significant factor of evaluating the positive attitudes on the sources (SR1, SR2, SR3 and SR4) of strategic risk (H4_SR1, H4_SR2, H4_SR3 and H4_SR4) between respondents of the Czech enterprises.

H5: The business sector is no statistically significant factor of evaluating the positive attitudes on the sources (SR1, SR2, SR3 and SR4) of strategic risk (H5_SR1, H5_SR2, H5_SR3 and H5_SR4) between respondents of the Slovak enterprises.

Following statistical tools of descriptive statistics (tables, descriptive characteristics - sum) were used in addressing the formulated hypotheses of partial research. We applied methods as absolute frequency and method of sorting the responses in evaluating of sources. The method of simple sorting was used to express the relative frequency of positive responses of the statement. Another used method was the relationship between qualitative variable of statistical characteristics (the source of strategic risk, the business sector, the nationality of respondent) utilizing contingency table and contingency intensity. Contingency intensity was measured using Pearson coefficient of contingency, which is based on the square contingency (Dvorský et al., 2019; Pepe et al., 1994). Z-score was used to determine significant statistical differences in the evaluation of sources of respondents' answers by nationality and business sector (Hudakova \& Dvorsky, 2019). 


\section{JOURNAL OF TOURISM AND SERVICES}

Issue 20, volume 11, ISSN 1804-5650 (Online)

www.jots.cz

The structure of respondents within the Czech Republic (454 enterprises) was the following: region of residence: 34 Zlín region, 29 Usti region, 29 Central Bohemian region, 22 Plzeň region, 30 Pardubice region, 41 Olomouc region, 53 Moravian-Silesian region, 29 Liberec region, 13 Hradec Králové region, 23 Region Vysočina, 21 Karlovy Vary region, 36 South Moravian region, 33 South Bohemian region, 61 Capital city Prague; by the period of operating a business: 27 enterprises less than 3 years, 28 enterprises from 3 to 5 years, 64 enterprises from 6 to 10 years, 335 enterprises more than 10 years; size of business: 290 micro-enterprises (less than 10 employees), 107 small enterprises (from 10 to 49 employees), and 57 medium-sized enterprises (from 50 to 249 employees); highest attained education level of the entrepreneur: 46 high schools without a diploma, 185high school with diploma, and 34bachelor's degree (Bc.), 168 master's degree (Ing./Mgr.) and 21 diploma degree (Ph.D.); gender of entrepreneurs: 323 men, 131 women; education related to the area of business: 171 yes (I do business in the area of my education), 158 somewhat related (some business processes are related to the area of my education) and 125 unrelated.

The structure of respondents within the Slovak Republic (368 enterprises) was the following: region of residence: 65 Prešov region, 42Košice region, 68 Bratislava region, 38 Banská Bystrica region, 32 Žilina region, 23 Trnava region, 59 Trenčín region, 40 Nitra region; by the period of operating a business: 23 enterprises less than 3 years, 50 enterprises from 3 to 5 years, 52 enterprises from 6 to 10 years, 263 enterprises more than 10 years; size of business: 216 micro-enterprises (less than 10 employees), 106 small enterprises (from 10 to 49 employees), and 46 medium-sized enterprises (from 50 to 249 employees); highest attained education level of the entrepreneur: 13 high schools without a diploma, 64high school with diploma, and 21bachelor's degree (Bc.), 234 master's degree (Ing./Mgr.) and 36 diploma degree (Ph.D.); gender of entrepreneurs: 323 men, 131 women; education related to the area of business: 138 yes (I do business in the area of my education), 140 somewhat related (some business processes are related to the area of my education) and 90 unrelated.

\section{Results}

The structure of respondents according the business sector in the Czech Republic is: 133 (29.3\%) services (SC), 91 (20.1\%) retailing (R), 79 (17.4\%) manufacturing (M), 63 (13.9\%) construction (C), 11 $(2.4 \%)$ tourism $(\mathrm{T}), 11(2.4 \%)$ agriculture $(\mathrm{A}), 10(2.2 \%)$ transportation $(\mathrm{TR}), 56(12.3 \%)$ another area of entrepreneurship (AA). The authors compare the attitudes of respondents between two groups of respondents in the Czech Republic (454 is 100\%): 133(29.3\%) services (SC) and 321 (70.7\%) other companies (OC).

The structure of respondents according the business sector in the Slovak Republic is: 107 (29.1\%) services (SC), 76 (20.7\%) retailing (R), 70(19.0\%) manufacturing (M), 41(11.1\%) construction (C), $15(4.1 \%)$ tourism $(\mathrm{T}), 8(2.2 \%)$ agriculture $(\mathrm{A}), 10(2.7 \%)$ transportation $(\mathrm{TR}), 41(11.1 \%)$ another area of entrepreneurship (AA). The authors compare the attitudes of respondents between two groups of respondents in the Slovak Republic (368 is 100\%): 107 (29.1\%) services (SC) and 261 (70.9\%) other companies (OC).

Table 1 summarises the results of the assessment of the strategic risk' sources of respondents according to and their nationality.

Table 1. Evaluation of respondents' attitude to the strategic risk sources

\begin{tabular}{|l|l|l|l|l|l|l|l|l|}
\hline \multirow{2}{*}{$\begin{array}{l}\text { Respondent } \\
\text { Attitudes }\end{array}$} & \multicolumn{4}{|l|}{ Czech republic } & \multicolumn{3}{l|}{ Slovak republic } \\
\cline { 2 - 9 } & SR1 & SR2 & SR3 & SR4 & SR1 & SR2 & SR3 & SR4 \\
\hline A1 + A2 & 377 & 227 & 295 & 213 & 294 & 204 & 243 & 188 \\
\hline $\mathbf{( \% )}$ & $83.0 \%$ & $50.0 \%$ & $65.0 \%$ & $46.9 \%$ & $79.9 \%$ & $55.4 \%$ & $66.0 \%$ & $51.1 \%$ \\
\hline A3 & 64 & 153 & 116 & 130 & 63 & 119 & 93 & 120 \\
\hline
\end{tabular}


JOURNAL OF TOURISM AND SERVICES

Issue 20, volume 11, ISSN 1804-5650 (Online)

www.jots.cz

\begin{tabular}{|c|c|c|c|c|c|c|c|c|}
\hline$(\%)$ & $14.1 \%$ & $33.7 \%$ & $25.5 \%$ & $28.7 \%$ & $17.1 \%$ & $32.3 \%$ & $25.3 \%$ & $32.6 \%$ \\
\hline A4 + A5 & 13 & 74 & 43 & 111 & 11 & 45 & 32 & 60 \\
\hline$(\%)$ & $2.9 \%$ & $16.3 \%$ & $9.5 \%$ & $24.4 \%$ & $3.0 \%$ & $12.3 \%$ & $8.7 \%$ & $16.3 \%$ \\
\hline TC & \multicolumn{4}{|c|}{185.607} & \multicolumn{4}{|l|}{85.758} \\
\hline $\mathbf{P}$ - value & \multicolumn{4}{|c|}{$<0,001$} & \multicolumn{4}{|l|}{$<0,001$} \\
\hline
\end{tabular}

Source: own data collection.

Note: SR1 - Strategic risk 1, .., SR4 - Strategic risk 4; TC - Test criterion; A1, .., A5 - type of answer of respondent.

The results showed, that $83 \%$ of SMEs use strategic management in a company (an integral part of corporate governance) according to Czech respondents' attitudes and 79.9\% according to Slovak respondents' attitudes. Also, that $46.9 \%$ of SMEs regularly monitor, evaluates and manages strategic risks according to Czech respondents' attitudes and 51.1\% according to Slovak respondents' attitudes. Also, that $50.0 \%$ of SMEs said, that strategic management is implemented in the everyday life of the company and realized through action plans programs according to Czech respondents' attitudes and 55.4\% according to Slovak respondents' attitudes. Also, that $65.0 \%$ of SMEs said, that proper strategic management improves the competitive the ability of company according to Czech respondents' attitudes and $66.0 \%$ according to Slovak respondents' attitudes. There are statistically significant differences between attitudes of respondents on the selected sources of the strategic risk in the Czech Republic (TC $=185.607 ; \mathrm{p}$-value is less than 0.05). There are statistically significant differences between attitudes of respondents on the selected sources of the strategic risk in the Slovak Republic (TC $=85.758$; $\mathrm{p}$-value is less than 0.05). The null hypotheses H1_CR and H1_SR are rejected.

The structure of the entrepreneurs' answers (source SR1 of strategic risk) according to the business sector (BS; SC - Service companies, OC - Other companies) and nationality (CR - Czech Republic; SR - Slovak Republic) were: CR: (OC/SC) - A1 - 135/50; A2 - 128/64; A3 - 49/15; A4 7/1; A5 - 2/3 and SR: (OC/SC) - A1 - 90/29; A2 - 118/57; A3 - 46/17; A4 - 5/2; A5 - 2/2. The following table 2summarise the results of the assessment of the strategic risk' source (SR1) of respondents according to the business sector and their nationality.

Table 2. Evaluation of respondents' attitude to the strategic risk source SR1

\begin{tabular}{|c|c|c|c|c|c|c|}
\hline \multirow{3}{*}{ SR1 } & \multirow{2}{*}{\multicolumn{2}{|c|}{$\begin{array}{l}\text { Czech republic } \\
\text { Business sector }\end{array}$}} & \multirow{3}{*}{$\begin{array}{l}\text { Z-score } \\
\text { p-value }\end{array}$} & \multirow{2}{*}{\multicolumn{2}{|c|}{$\begin{array}{l}\text { Slovak republic } \\
\text { Business sector }\end{array}$}} & \multirow{3}{*}{$\begin{array}{l}\text { Z-score } \\
\text { p-value }\end{array}$} \\
\hline & & & & & & \\
\hline & OC & SC & & OC & SC & \\
\hline $\mathbf{A} 1+\mathbf{A} 2$ & 263 & 114 & \multirow{2}{*}{$\begin{array}{c}-0.977 \\
0.327\end{array}$} & 208 & 86 & \multirow{2}{*}{$\begin{array}{c}-0.148 \\
0.881\end{array}$} \\
\hline$(\%)$ & $81.9 \%$ & $85.7 \%$ & & $79,7 \%$ & $80,4 \%$ & \\
\hline A3 & 49 & 15 & & 46 & 17 & \\
\hline$(\%)$ & $15.3 \%$ & $11.3 \%$ & & $17,6 \%$ & $15,9 \%$ & \\
\hline $\mathrm{A} 4+\mathrm{A} 5$ & 9 & 4 & & 7 & 4 & \\
\hline$(\%)$ & $2.8 \%$ & $3.0 \%$ & & $2,7 \%$ & $3,7 \%$ & \\
\hline SUM & 321 & 133 & & 261 & 107 & \\
\hline$(\%)$ & $100.0 \%$ & $100.0 \%$ & & $100,0 \%$ & $100,0 \%$ & \\
\hline TC & \multicolumn{2}{|c|}{1.236} & & \multicolumn{2}{|c|}{0.421} & \\
\hline p-value & \multicolumn{2}{|c|}{0.539} & & \multicolumn{2}{|c|}{0.810} & \\
\hline
\end{tabular}

Source: own data collection.

Note: SR1 - Strategic risk 1; OC - Other companies; SC - Service companies; TC - Test criterion; A1, ..., A5 - type of answer of respondent.

Around $81.9 \%$ of the Czech and $79.7 \%$ of the Slovak small and medium-sized enterprises of service reported that strategic management in a company is an integral part of corporate governance. The 


\section{JOURNAL OF TOURISM AND SERVICES}

Issue 20, volume 11, ISSN 1804-5650 (Online)

www.jots.cz

business sector isn't a significant factor. The respondents' attitudes (according service and other companies) are similar. The null hypotheses H2_SR1, H3_SR1, H4_SR1, and H5_SR1 are no rejected.

The structure of the entrepreneurs' answers (source SR2 of strategic risk) according to the business sector (BS; SC - Service companies, OC - Other companies) and nationality (CR - Czech Republic; SR - Slovak Republic) were: CR: (OC/SC) - A1 - 57/23; A2 - 102/45; A3 - 108/45; A4 37/12; A 5 - 17/8 and SR: (OC/SC) - A1 -43/15; A2 - 105/41; A3 - 77/42; A4 - 30/7; A5 - 6/2. The following table 3summarise the results of the assessment of the strategic risk' source (SR2) of respondents according to the business sector and their nationality.

Table 3. Evaluation of respondents' attitude to the strategic risk source SR2

\begin{tabular}{|c|c|c|c|c|c|c|}
\hline \multirow{3}{*}{ SR2 } & \multirow{2}{*}{\multicolumn{2}{|c|}{$\begin{array}{l}\text { Czech republic } \\
\text { Business sector }\end{array}$}} & \multirow{3}{*}{$\begin{array}{l}\text { Z-score } \\
\text { p-value }\end{array}$} & \multirow{2}{*}{\multicolumn{2}{|c|}{$\begin{array}{l}\text { Slovak republic } \\
\text { Business sector }\end{array}$}} & \multirow{3}{*}{$\begin{array}{l}\text { Z-score } \\
\text { p-value }\end{array}$} \\
\hline & & & & & & \\
\hline & OC & SC & & OC & SC & \\
\hline $\mathbf{A} 1+\mathbf{A} 2$ & 159 & 68 & \multirow{4}{*}{$\begin{array}{c}-0.309 \\
0.757 \\
\end{array}$} & 148 & 56 & \multirow{4}{*}{$\begin{array}{l}0.766 \\
0.441 \\
\end{array}$} \\
\hline$(\%)$ & $49.5 \%$ & $51.1 \%$ & & $56.7 \%$ & $52.3 \%$ & \\
\hline A3 & 108 & 45 & & 77 & 42 & \\
\hline$(\%)$ & $33.6 \%$ & $33.8 \%$ & & $29.5 \%$ & $39.3 \%$ & \\
\hline $\mathrm{A} 4+\mathrm{A} 5$ & 54 & 20 & & 36 & 9 & \\
\hline$(\%)$ & $16.8 \%$ & $15.0 \%$ & & $13.8 \%$ & $8.4 \%$ & \\
\hline SUM & 321 & 133 & & 261 & 107 & \\
\hline$(\%)$ & $100.0 \%$ & $100.0 \%$ & & $100.0 \%$ & $100.0 \%$ & \\
\hline TC & \multicolumn{2}{|c|}{0.232} & & \multicolumn{2}{|c|}{4.289} & \\
\hline p-value & \multicolumn{2}{|c|}{0.890} & & \multicolumn{2}{|c|}{0.117} & \\
\hline
\end{tabular}

Note: SR2 - Strategic risk 2; OC - Other companies; SC - Service companies; TC - Test criterion; A1, ..., A5 - type of answer of respondent.

Around $49.5 \%$ of the Czech and $56.7 \%$ of the Slovak small and medium-sized enterprises of service reported that strategic management is implemented in the everyday life of our company and realised through action plans and programs. The business sector isn't a significant factor. The respondents' attitudes (according service and other companies) are similar. The null hypotheses H2_SR2, H3_SR2, H4_SR2 and H5_SR2 are no rejected.

The structure of the entrepreneurs' answers (source SR3 of strategic risk) according to the business sector (BS; SC - Service companies, OC - Other companies) and nationality (CR - Czech Republic; SR - Slovak Republic) were: CR: (OC/SC) - A1 - 88/36; A2 - 121/50; A3 - 83/33; A4 23/10; A5 - 6/4 and SR: (OC/SC) - A1 - 65/29; A2 - 106/43; A3 - 67/26; A4 - 20/7; A5 - 3/2. The following table 4summarise the results of the assessment of the strategic risk' source (SR3) of respondents according to the business sector and their nationality.

Table 4. Evaluation of respondents' attitude to the strategic risk source SR3

\begin{tabular}{|c|c|c|c|c|c|c|}
\hline \multirow{2}{*}{ SR3 } & \multicolumn{2}{|c|}{ Czech republic } & \multirow{2}{*}{ Z-score } & \multicolumn{2}{|c|}{ Slovak republic } & \multirow{2}{*}{ Z-score } \\
\cline { 2 - 3 } \cline { 5 - 6 } & \multicolumn{2}{|c|}{ Business sector } & & \multicolumn{2}{|c|}{ Business sector } & \\
\cline { 2 - 3 } & $\mathbf{O C}$ & $\mathbf{S C}$ & p-value & OC & SC & p-value \\
\hline $\mathbf{A 1}+\mathbf{A 2}$ & 209 & 86 & 0.091 & 171 & 72 & -0.326 \\
\hline $\mathbf{( \% )}$ & $65.1 \%$ & $64.7 \%$ & 0.928 & $65.5 \%$ & $67.3 \%$ & 0.741 \\
\hline $\mathbf{A 3}$ & 83 & 33 & & 67 & 26 & \\
\hline $\mathbf{( \% )}$ & $25.9 \%$ & $24.8 \%$ & & $25.7 \%$ & $24.3 \%$ & \\
\hline $\mathbf{A 4}+\mathbf{A 5}$ & 29 & 14 & & 23 & 9 & \\
\hline $\mathbf{( \% )}$ & $9.0 \%$ & $10.5 \%$ & & $8.8 \%$ & $8.4 \%$ & \\
\hline
\end{tabular}




\section{JOURNAL OF TOURISM AND SERVICES}

Issue 20, volume 11, ISSN 1804-5650 (Online) www.jots.cz

\begin{tabular}{|c|c|c|c|c|}
\hline SUM & 321 & 133 & 261 & 107 \\
\hline$(\%)$ & $100.0 \%$ & $100.0 \%$ & $100.0 \%$ & $100.0 \%$ \\
\hline TC & \multicolumn{2}{|c|}{0.264} & \multicolumn{2}{|c|}{$\frac{1}{0.107}$} \\
\hline p-value & \multicolumn{2}{|c|}{0.876} & \multicolumn{2}{|c|}{0.948} \\
\hline
\end{tabular}

Source: own data collection

Note: SR3 - Strategic risk 3; OC - Other companies; SC - Service companies; TC - Test criterion; A1, ..., A5 - type of answer of respondent.

Around $65.1 \%$ of the Czech and $65.5 \%$ of the Slovak small and medium-sized enterprises of service reported that proper strategic management improves the competitive ability of our company and its stability in domestic and foreign markets. The business sector isn't a significant factor. The respondents' attitudes (according service and other companies) are similar. The null hypotheses H2_SR3, H3_SR3, H4_SR3, and H5_SR3 are no rejected.

The structure of the entrepreneurs' answers (source SR4 of strategic risk) according to the business sector (BS; SC - Service companies, OC - Other companies) and nationality (CR - Czech Republic; SR - Slovak Republic) were: CR: (OC/SC) - A1 - 54/18; A2 - 92/49; A3 - 96/34; A4 54/16; A5 - 25/16 and SR: (OC/SC) - A1 - 32/17; A2 - 104/35; A3 - 80/40; A4 - 37/11; A5 - 8/4. The following table 5summarise the results of the assessment of the strategic risk' source (SR4) of respondents according to the business sector and their nationality.

Table 5. Evaluation of respondents' attitude to the strategic risk source SR4

\begin{tabular}{|c|c|c|c|c|c|c|}
\hline \multirow{3}{*}{ SR4 } & \multirow{2}{*}{\multicolumn{2}{|c|}{$\begin{array}{l}\text { Czech republic } \\
\text { Business sector }\end{array}$}} & \multirow{3}{*}{$\begin{array}{l}\text { Z-score } \\
\text { p-value }\end{array}$} & \multirow{2}{*}{\multicolumn{2}{|c|}{$\begin{array}{l}\text { Slovak republic } \\
\text { Business sector }\end{array}$}} & \multirow{3}{*}{$\begin{array}{l}\text { Z-score } \\
\text { p-value }\end{array}$} \\
\hline & & & & & & \\
\hline & OC & SC & & OC & SC & \\
\hline $\mathbf{A} 1+\mathbf{A} 2$ & 146 & 67 & \multirow{2}{*}{$\begin{array}{r}-0.951 \\
0.342 \\
\end{array}$} & 136 & 52 & \multirow{2}{*}{$\begin{array}{l}0.611 \\
0.542\end{array}$} \\
\hline$(\%)$ & $45.5 \%$ & $50.4 \%$ & & $52.1 \%$ & $48.6 \%$ & \\
\hline A3 & 96 & 34 & & 80 & 40 & \\
\hline$(\%)$ & $29.9 \%$ & $25.6 \%$ & & $30.7 \%$ & $37.4 \%$ & \\
\hline $\mathbf{A} 4+\mathbf{A 5}$ & 79 & 32 & & 45 & 15 & \\
\hline$(\%)$ & $24.6 \%$ & $24.1 \%$ & & $17.2 \%$ & $14.0 \%$ & \\
\hline SUM & 321 & 133 & & 261 & 107 & \\
\hline$(\%)$ & $100.0 \%$ & $100.0 \%$ & & $100.0 \%$ & $100.0 \%$ & \\
\hline TC & \multicolumn{2}{|c|}{1.111} & & \multicolumn{2}{|c|}{1.721} & \\
\hline p-value & \multicolumn{2}{|c|}{0.574} & & \multicolumn{2}{|c|}{0.423} & \\
\hline
\end{tabular}

Note: SR4 - Strategic risk 4; OC - Other companies; SC - Service companies; TC - Test criterion; A1, ..., A5 - type of answer of respondent.

Around $45.5 \%$ the Czech and 52.1\% the Slovak small and medium-sized enterprises of service reported that regularly monitors, evaluates and manages strategic risks. The business sector isn't a significant factor. The respondents' attitudes (according service and other companies) are similar. The null hypotheses H2_SR4, H3_SR4, H4_SR4, and H5_SR4 are no rejected.

\section{Conclusion}

The aim of the article was to define important factors of strategic management in the service sector and compare the situation in Czech Republic and Slovak Republic. 


\section{JOURNAL OF TOURISM AND SERVICES}

Issue 20, volume 11, ISSN 1804-5650 (Online)

www.jots.cz

The results showed interesting findings. The results showed, that $85.7 \%$ of Czech SMEs of service use strategic management in a company an integral part of corporate governance $(80.4 \%$ of Slovak SMEs of service). On the other hand, that only $50.4 \%$ of Czech SMEs of service regularly monitors, evaluates and manages strategic risks (48.6\% of Slovak SMEs of service). The business sector is no statistically significant factor of evaluating the sources of strategic risk between respondents of the Czech enterprises (also of the Slovak enterprises). The business sector is not a statistically significant factor of evaluating the positive attitudes on the sources of strategic risk between respondents of the Czech enterprises (also of the Slovak enterprises).

The authors are aware of the limitations of the case study (e.g. the local study - only 2 Central European countries; the number of SMEs - only 822; verification of results using one methodology). The authors believe that the paper may bring some interesting findings and new incentives for further research and discussion on the cross-sectoral assessment of the strategic management and its important factors.

Our future research will focus on comparing other factors that determine the selected business sector of SMEs. These are mainly the areas of enterprise risk management, as are sources of market risk and of financial risk; of legal and of personal risk; of operational risk. We assume that the attitudes of SMEs towards the above risks will bring different perceptions.

\section{References}

1. Andrews, R., Beynon, M., \& Genc, E. (2017). Strategy Implementation Style and Public Service Effectiveness, Efficiency and Equity. Administrative Sciences, 7(1), 4. doi: https://doi.org/10.3390/admsci7010004.

2. Androniceanu, A. (2019). Social responsibility, an essential strategic option for a sustainable development in the field of bio-economy. Amfiteatru Economic, 21(52), 347-364.

3. Androniceanu, A., Tvaronavičienè, M. (2019). Developing a holistic system for social assistance services based on effective and sustainable partnerships. Administratie si Management Public, 33, 103-118. doi: https://doi.org/10.24818/amp/2019.33-06.

4. Arunruangsirilert, T., \& Chonglerttham, S. (2017). Effect of corporate governance characteristics on strategic management accounting in Thailand. Asian Review of Accounting, 25(1), 85-105. doi: https://doi.org/10.1108/ARA-11-2015-0107.

5. Barbosa, M., Castañeda Ayarza, J. A., \& Lombardo Ferreira, D. H. (2020). Sustainable Strategic Management (GES): Sustainability in small business. Journal of Cleaner Production, 258, 11. doi: https://doi.org/10.1016/j.jclepro.2020.120880.

6. Belás, J., Khan, K.A., Maroušek, J., \& Rozsa, Z. (2020). Perceptions of the importance of business ethics in SMEs: A comparative study of Czech and Slovak entrepreneurs. Ethics \& Bioetics (in Central Europe), 10(1-2), 96-106. doi: 10.2478/ebce-2020-0010.

7. Buganová, K., \& Hudáková, M. (2015). Increase of the competitiveness of enterprises through the implementation of risk management projects in slovakia. Paper presented at the WMSCI 2015 - 19th World Multi-Conference on Systemics, Cybernetics and Informatics, Proceedings, 2, 394-398. Retrieved from www.scopus.com.

8. Carreras, A. B. L., Arroyo, J. C., \& Blanco, J. E. E. (2018). Influence of the strategic planning and the management skills as factors internal of business competitiveness of SME's. Contaduria $y$ Administracion, 63(3), 19. doi: https://doi.org/10.22201/fca.24488410e.2018.1085.

9. Cepel, M., Stasiukynas, A., Kotaskova, A., Dvorsky, J. (2018). Business Environment Quality Index in the SME Segment. Journal of Competitiveness, 10(1), 21-40. doi: 10.7441/joc.2018.02.02.

10. Cešnovar, T. (2006). The impact of strategic management on business outcomes: Empirical research. Journal for East European Management Studies, 11(3), 227-243. doi: https://doi.org/http://hdl.handle.net/10419/84001.

11. Drew, S. A., Kelley, P. C., \& Kendrick, T. (2006). CLASS: Five elements of corporate governance 


\section{JOURNAL OF TOURISM AND SERVICES}

Issue 20, volume 11, ISSN 1804-5650 (Online) www.jots.cz

to manage strategic risk. Business Horizons, 49(2), 127-138. doi: https://doi.org/10.1016/j.bushor.2005.07.001.

12. Dvorský, J., Petráková, Z., \& Polách, J. (2019). Assessing the Market, Financial and Economic Risk Sources By Czech and Slovak Smes. International Journal of Entrepreneurial Knowledge, 7(2), 30 40. doi: https://doi.org/10.37335/ijek.v7i2.91.

13. Durica, M., Frnda, J., \& Svabova, L. (2019). Decision tree based model of business failure prediction for Polish companies. Oeconomia Copernicana, 10(3), 453-469. doi: https://doi.org/10.24136/oc.2019.022.

14. Elbanna, S., Andrews, R., \& Pollanen, R. (2016). Strategic Planning and Implementation Success in Public Service Organizations: Evidence from Canada. Public Management Review, 18(7), 10171042. doi: https://doi.org/10.1080/14719037.2015.1051576.

15. European Commission. (2016). European Semester Thematic Factsheet: Services. Retrieved from https://ec.europa.eu/info/sites/info/files/european-semester_thematicfactsheet_services_en.pdf.

16. European Commission. (2020). An SME Strategy for a sustainable and digital Europe (Intergovernmental Panel on Climate Change, ed.). doi: https://doi.org/10.1017/CBO9781107415324.004.

17. Felício, J. A. (2013). Study on the characteristics of top managers and strategic options in different industries over a time period. Global Business Perspectives, 1(3), 239-260. doi: https://doi.org/10.1007/s40196-013-0018-3.

18. Fernández-Vázquez, J.S. \& Álvarez-Delgado, R.A. (2019). Persuasive strategies in the SME entrepreneurial pitch: Functional and discursive considerations, Economic Research-Ekonomska Istrą̌ivanja. doi: https://doi.org/10.1080/1331677X.2019.1683462.

19. Foerster-Pastor, U.S., Golowko, N., Hell, C.R., Marquardt, K. (2019). Creating talent pools through coopetition: a case study on vocational training programs in Romania. Management \& Marketing. Challenges for the Knowledge Society, 14(2), 203-219.

20. Fonseca, L.M., Portela, A.R., Duarte, B., Queirós, J., Paiva, L.(2018). Mapping higher education for sustainable development in Portugal. Management \&Marketing. Challenges for the Knowledge Society, 13(3), 1064-1075, https://doi.org/10.2478/mmcks-2018-0023.

21. Frantz, E., Dugan, A., Hinchberger, K., Maseth, B., Al Sharfa, O., \& Al-Jaroodi, J. (2017). SMEs: The effects of strategic management. 2017 IEEE Technology \& Engineering Management Conference (TEMSCON), 388-393. doi: https://doi.org/10.1109/TEMSCON.2017.7998406.

22. Fuertes, G., Alfaro, M., Vargas, M., Gutierrez, S., Ternero, R., \& Sabattin, J. (2020). Conceptual Framework for the Strategic Management: A Literature Review - Descriptive. Journal of Engineering. doi: https://doi.org/10.1155/2020/6253013.

23. Gallardo-Vázquez, D., \& Lizcano-Álvarez, J. L. (2020). CSR-relatedcompetitiveness and legitimacy in MSMEs. Economics and Sociology, 13(1), 52-73. doi: https://doi.org/10.14254/2071789X.2020/13-1/4.

24. Günther, K. (2016). Key Factors for Successful Implementation of a Sustainability Strategy. Journal of Applied Leadership and Management, 4, 1-20.

25. Honggowati, S., Rahmawati, R., Aryani, Y. A., \& Probohudono, A. N. (2017). Corporate Governance and Strategic Management Accounting Disclosure. Indonesian Journal of Sustainability Accounting and Management, 1(1), 23. doi: https:// doi.org/10.28992/ijsam.v1i1.24.

26. Hudakova, M., \& Dvorsky, J. (2019). Analysis of the market risk sources in the small and mediumsized enterprises of transport. Communications - Scientific Letters of the University of Zilina, 21(4), 97103.

27. Hudakova, M., Masar, M., Luskova, M., \& Patak M.R. (2018). The Dependence of Perceived Business Risks on the Size of SMEs. Journal of Competitiveness, 10(4), 54-69. doi: https://doi.org/10.7441/joc.2018.04.04.

28. Ivanova, A. S., Holionko, N. G., Tverdushka, T. B., Olejarz, T., \& Yakymchuk, A. Y. (2019). The 


\section{JOURNAL OF TOURISM AND SERVICES}

Issue 20, volume 11, ISSN 1804-5650 (Online)

www.jots.cz

Strategic Management in Terms of an Enterprise's Technological Development. Journal of Competitiveness, 11(4), 40-56. doi: https://doi.org/10.7441/joc.2019.04.03.

29. Kalchenko, S., Trusova, N., Hrybova, D., \& Serhii, B. (2018). The small and large business interaction within national economy's gross added value reproduction in Ukraine. Oeconomia Copernicana, 9(3), 403-417. doi: https://doi.org/10.24136/oc.2018.020.

30. Kiseláková, D., Šofranková, B., Onuferová, E., \& Čabinová, V. (2019). The evaluation of competitive position of EU-28 economies with using global multi-criteria indices. Equilibrium. Quarterly Journal of Economics and Economic Policy, 14(3), 441-462. doi: https://doi.org/10.24136/eq.2019.021.

31. Ključnikov, A., Belás, J., Smrčka, L. (2016). Risk-taking and Aggressiveness as the Significant Part of the Entrepreneurial Orientation of SMEs: Case of the Czech Republic. Polish Journal of Management Studies, 14(1), 129-139. doi: https://dx.doi.org/10.17512/pjms.2016.14.1.12.

32. Korzh, N., Mostenska, T., Bilan, Y. (2017). Resource-based view in managing financial component of corporate capital. Polish Journal of Management Studies, 16(2), 133-146. doi: https://dx.doi.org/ 10.17512/pjms.2017.16.2.12.

33. Kot, S. (2018). Sustainable supply chain management in small and medium enterprises. Sustainability, 10(4), 1143.

34. Kot, S., Haque, A., Kozlovski, E. (2019). Strategic SCM's mediating effect on the sustainable operations: Multinational perspective. Organizacija, 52(3), 219-235.

35. Kubíčková, K., \& Hodžić, M. (2019). The evaluation of project management practices in the Czech social enterprises, Economic Research-Ekonomska Istrą̌ivanja. doi: https://doi.org/ 10.1080/1331677X.2018.1553679.

36. Lewandowska, A., \& Stopa, M. (2018). SMEs innovativeness and institutional support system: the local experiences in qualitative perspective. Polish case study. Oeconomia Copernicana, 9(2), 333351. doi: https://doi.org/10.24136/oc.2018.017.

37. Lewandowska, A., \& Stopa, M. (2019). Do SME's innovation strategies influence their effectiveness of innovation? Some evidence from the case of Podkarpackie as peripheral region in Poland. Equilibrium. Quarterly Journal of Economics and Economic Policy, 14(3), 521-536. doi: https://doi.org/10.24136/eq.2019.025.

38. Lyulyov, O. V., \& Pimonenko, T. V. (2017). Lotka-Volterra model as an instrument of the investment and innovative processes stability analysis. Marketing and Management of Innovations, (1), 159-169. doi: https://doi.org/10.21272/mmi.2017.1-14

39. Mura, L., Marchevska, M., \& Dubravska, M. (2018). Slovak retail business across panel regression model. Marketing and Management of Innovations, (4), doi: 203-211. https://doi.org/10.21272/mmi.2018.4-18

40. Nosková, M., \& Peráček, T. (2019). Termination of employment in the Slovak Republic as a key issue of HR Management. Central European Journal of Labour Law and Personnel Management, 2 (2), 44-59. doi: https://dx.doi.org/10.33382/cejllpm.2019.03.04

41. Parnell, J. A. (2014). Strategic Management Management Theory and Practice (4th ed.). SAGE.

42. Pepe, M. S., Reilly, M., \& Fleming, T. R. (1994). Auxiliary outcome data and the mean score method. Journal of Statistical Planning and Inference, 42(1-2), 137-160. doi: https://doi.org/10.1016/0378-3758(94)90194-5.

43. Pisar, P., \& Bilkova, D. (2019). Controlling as a tool for SME management with an emphasis on innovations in the context of Industry 4.0. Equilibrium. Quarterly Journal of Economics and Economic Policy, 14(4), 763-785. doi: https://doi.org/10.24136/eq.2019.035.

44. Saltaji, I. M. (2013). Corporate governance relationship with strategic management. Internal Auditing and Risk Management, 2(30), 277-284.

45. Shen, W., \& Gentry, R. J. (2014). A cyclical view of the relationship between corporate governance and strategic management. Journal of Management and Governance, 18(4), 959-973. doi: https://doi.org/10.1007/s10997-012-9248-z. 


\section{JOURNAL OF TOURISM AND SERVICES}

Issue 20, volume 11, ISSN 1804-5650 (Online)

www.jots.cz

46. Stonehouse, G., \& Pemberton, J. (2002). Strategic planning in SMEs - some empirical findings. Management Decision, 40(9), 853-861. doi: https:// doi.org/10.1108/00251740210441072.

47. Szczepańska-Woszczyna, K. (2018). Strategy, Corporate Culture, Structure and Operational Processes as the Context for the Innovativeness of an Organization. Foundations of Management, 10 (1), 33-44. doi: https://dx.doi.org/10.2478/fman-2018-0004

48. Śvárová, M., \& Vrchota, J. (2013). Strategic management in micro, small and medium-sized businesses in relation to financial success of the enterprise. Acta Universitatis Agriculturae et Silviculturae Mendelianae Brunensis, 61(7), 2859-2866. doi: https://doi.org/10.11118/actaun201361072859.

49. Ungerman, O., Dedkova, J., \& Gurinova, K. (2018). The Impact of Marketing Innovation on the Competitiveness of Enterprises in the Context of Industry4.0. Journal of Competitiveness, 10(2), 132148. doi: 10.7441 /joc.2018.02.09.

50. Valaskova, K., Kliestik, T., \& Kovacova, M. (2018). Management of financial risks in Slovak enterprises using regression analysis. Oeconomia Copernicana, 9(1),105-121. doi: https://doi.org/10.24136/oc.2018.006.

51. Verbano, C., \& Venturini, K. (2013). Managing risks in SMEs: A literature review and research agenda. Journal of Technology Management and Innovation, 8(3), 186-197. doi: https://doi.org/10.4067/s0718-27242013000400017.

52. Volkova, A. (2015). Development Strategy for Service Companies. Procedia Economics and Finance, 27(15), 479-483. doi: https://doi.org/10.1016/s2212-5671(15)01024-2.

53. Vrchota, J., \& Rehor, P. (2017). Influence of strategies to determine the significance of the crisis by the managers of small and medium-sized enterprises. Serbian Journal of Management, 12(1), 5363. doi: https://doi.org/10.5937/sjm12-11138.

54. Williams, R. I., Smith, A., Aaron, J. R., Manley, S. C., \& McDowell, W. C. (2019). Small business strategic management practices and performance: A configurational approach. Economic ResearchEkonomska Istrazivanja , 0(0), 1-19. doi: https://doi.org/10.1080/1331677X.2019.1677488.

55. Wirtz, J., Tuzovic, S., \& Ehret, M. (2015). Global business services: Increasing specialization and integration of the world economy as drivers of economic growth. Journal of Service Management, 26(4), 565-587. doi: https://doi.org/10.1108/JOSM-01-2015-0024.

\section{Brief description of Authors:}

\section{Ing. Ján Dvorský, PhD.}

Department of Business Administration, Faculty of management and economics, Tomas Bata University in Zlín, Mostní 5139, 76001 Zlín, Czech Republic, www.utb.cz, j1dvorsky@,utb.cz. His research is focused on Enterprise Economics, Quality of Business Environment, Risk Management, Small and Medium size Enterprise and Education of students in the economic field. He is a lecturer and a teacher of Applied Statistics and Econometric, Managerial Accounting II, Management Accounting and Enterprise Economics I. He published 31 scientific articles on database Scopus (h-index = 7) and 22 scientific articles on database Web od Science (h-index $=5)$.

\section{Assoc. Prof. Zora Petráková, PhD.}

Institute of forensic Engineering, Faculty of Civil Engineering, Slovak University of Technology, Radlinského 11, 81005 Bratislava, Slovak republic, www.stuba.sk, zora.petrakova@stuba.sk. She delivers forensic and economic assessments in difficult issues demanding expert witnesses on construction claims advanced to trials and other tribunals for resolution in behalf of citizens and organizations according to Slovak state legislation. She provides lectures in Forensic and economic engineering for full-time students. He published 4 scientific articles on database Scopus $(\mathrm{h}$-index $=2)$ and 3 scientific articles on database Web od Science (h-index = 2). 


\section{JOURNAL OF TOURISM AND SERVICES}

Issue 20, volume 11, ISSN 1804-5650 (Online)

www.jots.cz

\section{Ajaz Khan Khurram}

Department of Business Administration, Faculty of management and economics, Tomas Bata University in Zlín, Mostní 5139, 76001 Zlín, Czech Republic, khan@utb.cz, www.utb.cz. He is external PhD. Students. His research is Business environment.

\section{doc. Dr. Ing. Ivo Formánek}

Department of Entrepreneurship and Management, Institute of Entrepreneurship and Marketing, University of Entrepreneurship and Law, Vltavská 585/14, 15000 Praha, Czech Republic, ivo.formanek@vspp.cz, www.vspp.cz. He is a member of the academic staff and he also acts as a guarantor and manager of corporate education. His main professional interest nowadays is industrial engineering and management and optimization of business processes and projects. In these areas, he cooperates with a number of companies from industrial practice.

\section{prof. Ing. Zdeněk Mikoláš, CSc.}

Department of Entrepreneurship and Management, Institute of Entrepreneurship and Marketing, University of Entrepreneurship and Law, Vltavská 585/14, 15000 Praha, Czech Republic, zdenek.mikolas@vspp.cz, www.vspp.cz. He is a guarantor of the study program Economics and Management and a guarantor of the study field Entrepreneurship. He focuses on economics and business management, entrepreneurship and business environment for a long time. He has written or co-authored hundreds of articles, conference papers, scripts, books, etc. - such as "How to Increase Business Competitiveness" or "Competitive Potential of Industrial Enterprise" and other books and articles published in Poland, Slovakia, France, USA, Taiwan etc. 